\title{
The response strategy of social work with displaced families and the receiving community (within the context of sustainable development)
}

\author{
Iryna Trubavina ${ }^{1,}$, Olena Karaman $^{2}$, Dimitrina Kamenova ${ }^{3}$, Viktoriia Stepanenko $^{2}$, and Yaroslava Yurkiv $^{2}$ \\ ${ }^{1}$ National Academy of the National Guard of Ukraine, Department of Socio-humanities subjects, 3 Zakhysnykiv Ukrainy Sq., Kharkiv, \\ 61001, Ukraine \\ ${ }^{2}$ Luhansk Taras Shevchenko National University, Department of Social Pedagogy, 1 Gogol Sq., Starobilsk, 92703, Ukraine \\ ${ }^{3}$ Varna University of Management, Department for Modern Educational Methods, 13A Oborishte Str., Varna, 9000, Bulgaria
}

\begin{abstract}
The article deals with the issues of overcoming poverty, inequality, nutrition improvement, ensuring a healthy way of life, raising education quality, enhancing well-being, and building up a peaceful and open society for internally displaced persons (IDP) and the receiving community by means of the social response strategy. The goal of the research: theoretic substantiation of the response strategy in social work with IDP and the community in the context of the perspective of ensuring their sustainable development. The presented response strategy is for the first time theoretically substantiated and adapted to the Ukrainian realities in the conflict zone and takes into account the peculiarities of the DP and social work in the receiving borderline community and includes standard actions to react to extraordinary situations, activity directions psychology-and-pedagogic, socio-medical, humanitarian, information-and-cultural assistance. The strategy is based on the principles of integration, multi-sidedness, multidisciplinary connection, resource-orientation, green-aware social work, the advantages theory, partnership, assistance for self-assistance, family-centrism, innovation, synergy, etc.; it takes into account the perspective ensuring of sustainable future for both the displaced families and the receiving community in general. The methods of the research: theoretical analysis, synthesis, systemizing, generalizing, comparison, documentation study, estimation of needs, and mathematic statistics methods. The obtained results of applying the mentioned theory under conditions of the military conflict in the Luhansk oblast (area) of Ukraine confirm its efficiency in qualitative and numerical terms and are supported by mathematic statistics methods.
\end{abstract}

\section{Introduction}

Overcoming poverty and hunger, reducing inequality, nutrition improvement, ensuring a healthy way of life, raising education quality, enhancing well-being for various age-groups of population, formation of a peaceful and open society as the goals of sustainable development, proclaimed in the UN General Assembly Resolution for the period till 2030 [1] and adopted by Ukraine [2], are the principal landmarks for working out social projects and programs for improvement of medical, social, and educational services for vulnerable strata of population in the context of securing their sustainable future $[3 ; 4]$. Attaining these goals is of special urgency in the east of Ukraine, where the military conflict has affected the population's well-being level, led to the arising of the new for the country vulnerable social group, internally displaced persons (IDP), the number of whom as of 13.04.2020 was $1,446,881$ according to the Unified information database on internally displaced persons of the Ministry of Social Policies of Ukraine. These people need support and assistance, including social work concerning a decrease in the conflict's consequences influences on their lives, securing their sustainable development, adaptation to the new communities, and integrating into new conditions of life. On the other hand, the arrival of IDP to new communities has led to the growth of tension therein, due to the need in sharing the existing resources among all the community members, thus making the receiving party poorer as a result of IDP' arrival. It is the border regions of Ukraine where this situation has formed along the demarcation line, where, for instance, in the city of Berdyansk there was registered the ratio of 1:5 between IDP and the local inhabitants which makes $20 \%$ of the population. An EU 1.3 mln euros project solved the issue of diminishing social problems, easing tensions between IDP and the receiving community of this city [6], but not all towns in the borderline zone get such financing. Other ways of solving the problems of IDP and local community are needed, like, among other things, activation of people themselves to render self-assistance, granting targeted assistance, and so on. The concepts of social work acting in Ukraine ("assistance for self-assistance", "crisis intervening") are characterized as rendering assistance for adults in the time of peace [7], while the conditions of a military conflict

\footnotetext{
* Corresponding author: trubavina@gmail.com
} 
attest to peculiar problems of socialization and activities of children, families, and adults [8;9]. The existing concepts of social work [10-12] insufficiently account for the peculiarities of IDP and the receiving community. Attention should be paid to strengthening and encouragement of communities, to satisfying the needs of all vulnerable families of IDP and local people from the receiving community, which is attained in practice by integrating resources and interdepartmental and multidisciplinary cooperation in rendering social services [6; 13-17]. Nevertheless, the mentioned measures overall do not facilitate the development of IDP and local people or communities. Other approaches are needed, targeted at sustainable development of every person, family, community under conditions of a humanitarian crisis and military conflict.

As to conception and formation of the ideas of sustainable development in social work, it should be noted that accentuation on individual sustainability (a personality sustainability) has existed in social work for a long time and has evolved as a concept, but it was not applied to IDP, particularly to children and their families that prevail among IDP [18]. In its turn, the interconnected vectors of social work and sustainable development of communities, society, of interaction between the personality, the family, and the community are a new direction that has become the reason for activation of research in this sphere to find ways of mobilizing resources of all IDP and the community, for development of strategies which will facilitate ensuring sustainable future $[6 ; 19-24]$. Such strategies have not been yet applied to IDP in Ukraine.

Among the researches by foreign scientists devoted to this topic, there are studies representing the theory and practices of social work with vulnerable strata of population, including IDP under conditions of a military conflict. Social work with them is based on eco-social foundations. Military actions are viewed as cause and effect of environment degradation (Aniche Alexander [25], J. Lambert [26], T. John Pardeck [27]; K. van Wormer et al. [28], and others). The impact of a military conflict on internally displaced children and families with the accentuation on their mental health, considering the displacements as a social ecology problem that determines deprivation, poverty, and social rejection, is presented in the works by K. Lai [29], K. Miller [30]. L. Dominelli within the concept of the green social work focuses on the problems of social injustice, social rejection, and segregation of people [31]. Historic development and dilemmas of social work with displaced population are represented in the work by P. Boccagni and E. Righard [32]. The issue of different consequences of internal displacements and IDP integration into receiving communities is elucidated by A. Carrillo [33]. These researches are related to the authors' studies of the IDP's problems [8], their life in the places of compact residence of IDP and social services for them in the receiving community [6] in the context of special problems of socialization and integration of internally displaced children and adults, the need in comprehensive solving their problems. The ecologic perspective in social work with the IDP and the community, according to the world studies, is based on support of a personality and their environment, satisfying their needs, search for and integration of resources for solving personal problems $[34 ; 35]$. Currently, social work in the global context of sustainable future is of multidisciplinary character and requires that a social worker perform the role of a coordinator of individual and social sustainability development [31] and is directed at overcoming of poverty, fair distribution of resources, decrease in the risks of negative consequences on the level of an individual, a family, a group, a community and society in general, integration of a personality into a community and accepting them by local people. This highlights the topicality of theoretic substantiation of the new theory of social work with IDP and community with taking into account the country's specifics, its particular region, and practical implementation of the principal guidelines in the activities of various social institutions in the context of the perspective of securing a sustainable future for the mentioned social group and the community.

In the international practice, social work with vulnerable strata of population that suffered as a result of a military conflict began developing after the World War II; it was non-existent in Ukraine. Nowadays, the Ukrainian system of social services appears to be unprepared for timely response to the new social problem, the arrival of IDP. That is why a portion of the work concerning rendering assistance to them was undertaken by international public organizations and volunteers [36]. One of such organizations is the International charity organization "SOS Children's Villages", whose general activity strategy for the period till 2030 is targeted at ensuring the best care of children, innovations introduction, uniting larger numbers of partners to solve the problems of children from the families that found themselves in difficult life situations, as well as to react to changeable needs of communities [37]. Its goals are closely related to the sustainable development goals in such spheres as poverty, inequality, education, healthcare, social protection, decent work, and fostering their achievement with the accentuation on the target group children and families. This supposes the work of the organization concerning improvement of national social protection systems, combating social inequality, promoting access to quality education, broadening opportunities for youths' employment, eliminating violation to children [38]. These aspects of the organization's activities are of global character because "SOS Children's Villages" operates in 136 countries and territories of the world [39]. They do not reflect the specifics of each state, but lay foundations for working out new theories of social work with children and their families taking into account the circumstances in a particular country, or in a particular region, which determines the expediency in utilizing their experience when developing new theories. This organization applies the responsive strategy of social work which is targeted at working with individuals, groups, and communities that have suffered from extraordinary situations (natural disasters, technogenic catastrophes, wars, etc.), restoring their activities, and access to resources [40]. But this 
strategy has not been theoretically substantiated and adapted to the realities of Ukraine.

Therefore, there is a need in solving the problems of IDP and community in socially unstable regions. Formation of new communities in such regions and securing for them a perspective of sustainable development is becoming even more acute and calls for substantiation of the new social work theory which the authors have determined to be the response strategy. Therefore, the goal of this article is theoretical substantiation of the response strategy in social work with internally displaced families and the community within the context of the perspective of ensuring their sustainable development.

Attaining the goal supposes solving the following tasks: 1) determining the peculiarities of social work with IDP and the community in Luhansk oblast; 2) substantiation and disclosing the essence of the response strategy in social work with IDP and communities at the areas bordering with the conflict zone in Luhansk oblast; 3) to estimate the efficiency of the response strategy's application on the mentioned theoretical foundations in Luhansk oblast.

\section{Methodology}

The main methods that ensured attaining the goal and the tasks of this research were theoretical analysis of sources on the studied problem, synthesis, systemizing, generalization, comparison, documentation study, needs estimation, mathematic statistics methods for comparing, evaluation and estimation of the obtained results. The base for the research was the work of the Luhansk area branch of the international charity organization "SOS Children's Villages" in the military conflict zone and the border regions.

The research was conducted within the partnership between the Science-and-research Center of Social Pedagogy Problems and Social Work at the National Academy of Pedagogic Sciences (hereinafter the Center) established on the base of State Institution "Luhansk Taras Shevchenko National University" on the one part, and the Luhansk area branch of the international charity organization "SOS Children's Villages" on the other part. The research was financed from the State budget of Ukraine as part of the fundamental research "Socializing of the school and student youth of the East of Ukraine under the hybrid was in Donbas" (2018-2020) [41] and in the course of participating in the international project on "Strengthening Communities for Ensuring the Children's and Families' Needs in the North of Luhansk Oblast" supported by the UNICEF and Luhansk oblast branch of the international charity organization "SOS Children's Villages International") [41; 42].

In the towns of Starobilsk and Severodonetsk, experimental sites were established to work with IDP, the community, and internally displaced children's villages. The materials of the conducted work have been generalized in this article.

\section{The results of the research}

\subsection{Peculiarities of social work in the conflict border regions}

The specifics of the operation of the Center and Luhansk oblast branch of "SOS Children's Villages" is that that the employed specialists' staff is composed of both local specialists and those who are IDP. For this reason, they like no other feel the problems and needs of internally displaced families in a new community. Another peculiarity in the Center's activities is that it takes place in Luhansk region, part of which is temporally occupied. On the territory which is controlled by Ukrainian government, the power is exercised by military-and-civil administrations for securing safety and normalizing population's activity, law order, taking part in counteracting aggression acts, subversive activity and terrorist acts, preventing humanitarian catastrophe [43]. This means the need in coordinating social work, its events with military-and-civil administrations for safety of social workers and the clients. Luhansk oblast is the second in Ukraine after Donetsk oblast by the number of IDP, which amounts to 280,437 people [44] and aggravates the situation considering that the area itself has suffered and is still experiences the consequences of the active conflict. Therefore, the peculiarity of rendering social services is the need in resources in the receiving community and the lack of these resources. At present, an aggravation of conflicts in all spheres of group interaction between IDP and representatives of receiving communities is observed, which is mostly determined by the absence of real public dialogue, ignoring the interests of all parties, taking unjustified decisions concerning socially significant issues [45]. That is why social management is important considering the problem of redistribution of the available resources. In Luhansk and Donetsk oblasts has formed the worst situation in Ukraine as to the state of satisfying the basic needs of people, which is determined by high unemployment level in these areas. In the areas, there is no support of IDP by local authorities who do not develop programs for IDP integration and do not provide for financing their social needs from local budgets. The reason is that IDP have no right to vote at local elections, not being permanent residents. Therefore, the peculiarity of social work is its orientation at those state programs that are limited in an area with military-and-civil administration, as well as at public organizations and citizens' self-assistance.

In the Center's activity and that of "SOS Children's Villages", resilience is actively applied, the approach that orientates social work at client's advantages that facilitates avoiding deep traumatizing of children and families that found themselves in dangerous or extreme conditions. Resilience is different from resistance to stress, which changes a person under the impact of outside events and influences. This notion supposes an individual's resistance to such influences, the absence of the result of influencing people. In the context of the research, the authors attempted to compare some 
peculiarities of social work in terms of applying standard approaches and that of resilience (Table 1).

Table 1. Comparing resilience with standard approaches to understanding a difficult life situation in social work ${ }^{*}$.

\begin{tabular}{|c|c|}
\hline $\begin{array}{l}\text { Standard approach - } \\
\text { when focusing on } \\
\text { deprivation, disorders, a } \\
\text { trauma }\end{array}$ & $\begin{array}{c}\text { Resilience - when orientated at a } \\
\text { person's advantages }\end{array}$ \\
\hline $\begin{array}{l}\text { Considering a person's } \\
\text { problem as a typical case }\end{array}$ & $\begin{array}{c}\text { Orientation at the personality's } \\
\text { uniqueness }\end{array}$ \\
\hline $\begin{array}{l}\text { Focusing attention on the } \\
\text { client's problem }\end{array}$ & $\begin{array}{l}\text { Focusing attention at potential } \\
\text { opportunities }\end{array}$ \\
\hline $\begin{array}{l}\text { Needs are determined by } \\
\text { social worker }\end{array}$ & $\begin{array}{l}\text { An individual determines their } \\
\text { needs independently (or with } \\
\text { social worker's assistance) }\end{array}$ \\
\hline $\begin{array}{l}\text { Difficult life situation is } \\
\text { perceived as a risk of } \\
\text { negative consequences }\end{array}$ & $\begin{array}{c}\text { Difficult life situation is perceived } \\
\text { as activation of a personality's } \\
\text { powerful inner resources which } \\
\text { had been used before }\end{array}$ \\
\hline $\begin{array}{l}\text { Inability to resist an } \\
\text { extraordinary situation }\end{array}$ & $\begin{array}{l}\text { Ability to overcome difficulties } \\
\text { caused by an extraordinary } \\
\text { situation, to preserve the balance } \\
\text { and stability }\end{array}$ \\
\hline
\end{tabular}

* Compiled by the authors as an example based on the exercise "Advantages theory in social work" [46].

Therefore, it is possible to determine the peculiarities of social work in Luhansk oblast: a larger number of clients' social problems compared with other regions, the majority of the clients are IDP, there exist specific problems of IDP and the receiving community, dependence of social work on military-and-civil administrations and the territory status, the need in social management under limited resources, involvement of IDP in social work as specialists, the absence of local assistance programs for IDS, orientation of state social services at state assistance programs for IDP that act on the territory of Ukraine and do not take into account the specifics of the territories in the conflict zone, involvement of public organizations in rendering social services to IDP and the community, orientation at resilience (focusing on the clients' advantages).

\subsection{Substantiation of the essence of the response strategy in social work in the military conflict zone}

The strategy of social work with clients of different age groups and categories is defined as part of a social worker's skills, which include its basic components connected with his/her ability to select for each presented task the optimal social technologies, methodologies, and tactics that would ensure its successful accomplishment [11]. A strategy's peculiarity is that if the strategy is chosen correctly and is of high quality, it does not need alterations regardless of the changes in environment, for it is in itself a precondition for survival in a constantly changing environment. Only the plan of measures is to be adjusted depending on the chosen strategy. At the same time, the measures should be integrated and mutually connected [47].
The response strategy in social work is meant for work with individuals, groups, and communities who have suffered from extraordinary situations (natural disasters, technogenic catastrophes, wars, etc.), for restoration of their activities and access to resources [40]. It is directed at overcoming the dependency on humanitarian aid, recuperation of work potential, socio-cultural and social relations, efficient self-management and self-assistance [36]. This strategy is maintained on the basis of observing both the legal norms (General Declaration of Human Rights [48], the UN Convention on Children's Rights [49], the UN Guidelines concerning Alternative Childcare [50], the UN Goals of Sustainable Development till 2030 [1] and others) and the developed inner standards in social services provision. Correspondently, the measures of the "SOS Children's Villages" organization and the Center on the issues of readiness for and reacting to extraordinary situations, planning for unforeseen circumstances, joint estimation and development of standards and guidelines, fulfilling of corresponding programs of rendering assistance in extraordinary situations, reacting to consequences of military actions, providing assistance for vulnerable strata of population, particularly to internally displaced children and families reflect the main priorities of the UN activities in this sphere. That is, the measures are oriented at observing the human rights, preserving the integrity of family, safety, and other basic needs of people.

It is stated in the UN Manual on Extraordinary Situations, that "any extraordinary situation is unique, that is why there is no single comprehensive plan to control it. Nevertheless, extraordinary situations usually develop on scenarios that have some common features, which enables specify standard actions in response" [51]. Analysis of the content of the response to extraordinary situations concerning the work with refugees in the UN documents, and in the practices of the "SOS Children's Villages" organization's operation has made it possible to establish the list and the main content of such actions (table 2).

The measures on rendering assistance to IDS as a new category of social services' clients for Ukraine are in many cases similar to those for refugees, although IDP, unlike refugees, remain on the territory of their country, therefore their protection and rights are regulated not so much by particular international legal acts as by national legislation [51]. That is why forming various conditions for their rights implementation and protecting them as the goal of social work enables using scientific approaches of human rights protection, a family-centered approach (of protecting the family, family members and their rights). The peculiarity of the response strategy in social work with IDP and community under conditions of the military conflict and social crisis in Luhansk oblast is that the safety issues are accentuated on, including those of evaluating the family and community's needs for creating a safe life, considering the project initiatives in local development in the context of vision of the perspectives of their sustainable future [52]. This means the need in utilizing all the benefits of the risk-orientated and the project-orientated approaches, of diagnostic social work. They enable solving locally the problems of community, 
decreasing danger and risks for people's life, and finding additional financing for problems solving.

Table 2. Standard actions within the response strategy to extraordinary situations

\begin{tabular}{|l|l|}
\hline \multicolumn{1}{|c|}{ Standard actions } & \multicolumn{1}{|c|}{ Contents of the actions } \\
\hline $\begin{array}{l}\text { Estimate the problem, } \\
\text { the needs and resources }\end{array}$ & $\begin{array}{l}\text { Initial estimation of the problem and } \\
\text { people's needs }\end{array}$ \\
\hline Mobilizing resources & $\begin{array}{l}\text { Activation and use of potential } \\
\text { resources in order to eliminate the } \\
\text { threat for people's life and health }\end{array}$ \\
\hline $\begin{array}{l}\text { Regulating the relations } \\
\text { with the donors and the } \\
\text { media }\end{array}$ & $\begin{array}{l}\text { Ensuring communication between } \\
\text { family members and relatives }\end{array}$ \\
\hline Planning operations & $\begin{array}{l}\text { Additional estimation of the client's } \\
\text { needs, development of the actions } \\
\text { plan, determining current tasks and } \\
\text { long-term goals and measures to } \\
\text { achieve them }\end{array}$ \\
\hline $\begin{array}{l}\text { Carrying out operations } \\
\text { and coordinating the } \\
\text { actions }\end{array}$ & $\begin{array}{l}\text { Tasks distribution, } \\
\text { coordination mechanisms of fulfilling } \\
\text { individual tasks }\end{array}$ \\
\hline $\begin{array}{l}\text { Monitoring } \\
\text { estimating the situation } \\
\text { constantly }\end{array}$ & $\begin{array}{l}\text { Estimation of the dynamics in changes } \\
\text { in the course of solving the problem, } \\
\text { comparing the initial, the intermediate, } \\
\text { and the final results of social work } \\
\text { with the client }\end{array}$ \\
\hline $\begin{array}{l}\text { Going on to the actions } \\
\text { following } \\
\text { termination of the an } \\
\text { extraordinary situation }\end{array}$ & $\begin{array}{l}\text { Completion of work, defining the } \\
\text { perspectives of renewing the work } \\
\text { with the client if needed }\end{array}$ \\
\hline
\end{tabular}

It should be noted that the response strategy in social work in the "SOS Children's Villages" activity is aimed at work with children and families that found themselves in difficult life situations, at renewal of their viability, access to resources, and integration into the receiving communities [53]. In essence, this strategy relies on the integration and the eco-social approaches, which are based on the foundations of partnership, viability, innovations, and synergy, and can include crisis intervening when a person or a family needs support in difficult and extraordinary situations, which is broader than the social work in difficult life situations conducted by the rest of social workers of Ukraine [not involved in work with IDP]. Due to the fact that such social work can be made by IDP themselves, the participation theory is important for the work with IDP and the community. Partnership in this sense of social work supposes conducting various consultations aimed at well-grounded expectations of the community from power bodies. All the interested parties - representatives of power bodies, scientific and educational institutions, enterprises, and other institutes of civil society - are invited to take part in passing decisions and development of strategic goals. This is the democratic approach in social work. Innovation acts as a kind of indicator of the response strategy projects and for the larger part relates to efficient use of available resources. The synergy approach supposes considering individuals, families, groups, and communities as self-organizing systems, especially in unstable, crisis states.

The idea of application of the integration approach is that social response to the clients' needs supposes not only their adapting to the community, but also the community's adapting to them, community's creating favorable conditions for the utmost implementation of its members' potential, strengthening inter-sectoral cooperation between different social institutions on partnership terms, provision of comprehensive social services [3]. This means the use of the resource approach in a community. An important role in this work is allotted to interdepartmental interaction, which supposes mutually coordinated activity of structural units of the local executive power body and the offices subordinated to them with involvement of other institutions and administrations representatives vested in authorities provided for by legislation if necessary for the best ensuring of the rights of children who reside or stay on their departmental territory, solving their families' problems, forming conditions for children's upbringing by their responsible parents or legal representatives. Interdepartmental interaction on the issues of assistance, support, and guiding a child and their family in the "SOS Children's Villages" operation supposes close cooperation between state organizations, healthcare system institutions, social protection of population, education, non-governmental organizations and institutions. Organizing such interaction in present conditions of development and improvement of social services for families should become the mechanism which facilitates attaining high standards in the sphere of rendering social services [54]. The interdepartmental approach supposes multidisciplinary operation, organizing and coordination of social services provision, systemacy in rendering them, which means integration and cooperation of all structures and specialists, the basis of which may comprise, according to the human rights theory, of the family-centered approach, human rights, and family rights.

The eco-social approach departs from the idea of interconnection and interaction between an individual and the environment. A social worker's actions are directed at assisting a person to overcome a number of problems that are a consequence of this interaction. Social problems are viewed as ecological problems, and corresponding work is aimed at ensuring decent environmental conditions, ecological justice and equal access to natural resources, environment preservation, assistance to population in extraordinary situations [40]. It is access to water, medicines, food, and other essential things that matters most in the so-called "grey zones", in the conflictbordering areas. That is why socio-economic services are the foundation of satisfying people's basic needs and solving their daily problems. A task-oriented model of social work is needed. In eco-social approach, resilience requires "assistance for self-assistance", as well as training to perform resistance to outer negative influences and circumstances with relying on the positive in the situation and the person.

Thus, the theoretical foundations of the response strategy in the Center's social work with IDP and community in Luhansk oblast are scientific approaches of various levels, namely:

Philosophic approaches: the human rights theory, the sustainable development theory, the pragmatic the 
democratic, the multidisciplinary approaches, and the participation theory;

General science approaches: the integrated, the innovational, and the synergy approaches;

Specific science approaches: the family-centered, the risk-orientated, the project, and the resource approaches;

Social work approaches: the advantages theory, assistance for self-assistance, crisis intervening, ecosocial, diagnostic social work, and task-oriented model.

The principles of social work based on the response strategy in Luhansk oblast are: observing human and family rights, orientation at sustainable development of a person and the community, subjectivity, viability, synergy, integration, cooperation, solving urgent problems, orientation at result, directedness at selfassistance and resilience, innovations introduction in problem solving, removing risks and dangers, their minimization, relying on local projects, joining resources, considering clients as subjects and in case of a crisis as objects of social work, work with environment and in community, problems and needs estimation, responding to problems and needs.

The content of the response measures on this basis should be determined departing from the problems, goals, and principles of work. Thus, the main problems of IDP in the East of Ukraine are the problems of obtaining temporal housing, residence registration, medical examination and treatment, education, food, clothes and hygiene products supply, coordination of procedures to get social assistance, the issues of work and employment, etc., which if not timely attended to will cause instability and loss of control over the situation and one's own life, abrupt decrease in material well-being, fear of being rejected by society, feeling of insecurity, and being unable to foresee one's future $[8 ; 55 ; 56 ; 57 ; 58]$. Also, as has been proved, outreach and socio-cultural work is needed [6]. That is why, the main directions in implementation of the response strategy in the Center's social work with IDP and the community are psychology-and-pedagogic, sociomedical, information-and-cultural, and humanitarian assistance. Each of these kinds of work can be performed at different levels of a case: from servicing to rehabilitation, support and intervening. It is these kinds of work that help gradually bring a person out of crisis and lead them to development without negative consequences for their life and health. The chief methods are the following: social, socio-psychological, sociopedagogical, socio-economic, organization, and diagnostic ones.

Within the authors' experimental research, each of the mentioned kinds of social work became a criterion in evaluating the efficiency of the response strategy application in the "SOS Children's Villages" organization and the Center in Luhansk oblast, and the chief methods of social work mentioned in this connection were indicators of these criteria.

The experiment involved 250 families that found themselves in difficult life situations and were entitled to social support at "SOS Children's Villages" (towns Starobilsk and Severodonetsk) through the response strategy in social work. $80 \%$ of these families had the IDP status, while $20 \%$ of the families were locals. The answers to the questions concerning the need in these or other kinds of services were given by women as representatives of these families. The experiment supposed comparing the results obtained prior and following the social response actions, i.e. women's independent estimation of needs in obtaining different kinds of services before and after social support. The research was based on the standards of observing ethical principles of conducting research with humans as subjects. The families participated in the interviews on their free will.

At the initial stage of the experiment (October 2018) in the psychology-pedagogic assistance direction, the urgency in satisfying the needs of internally displaced families in logopedist services were estimated and amounted to $12 \%$ of the total number of families that agreed to participate in experimental actions concerning the response strategy application in the course of their social support. The needs in psychologist services were $84.4 \%$, in those of a social worker $-81.6 \%$, improvement of their knowledge of English - 25.6\%, catching up with the school program $-15.2 \%$. By the socio-medical assistance direction, the needs in covering families' expenditures on medical treatment of children were $31.6 \%$, recovery - $69.2 \%$, By the direction of information-and-cultural assistance, $64.4 \%$ of families needed information services, and $89.6 \%$ needed help in organization of daily activities and leisure. The families' needs in humanitarian aid were $88.4 \%$. The obtained data match the results of the research concerning the estimation of IDP's needs and employment possibilities in Ukraine $(n=2000)$ conducted in October 2014 December 2015 by the International Labor Organization, which estimated the unemployment percentage among the IDP due to looking after ill family members and young children to be $31.5 \%$ [59] and the research on estimation of IDP and services for them in Ukraine $(n=471)$ conducted by the international NGO "Social Initiatives in Labor Protection and Healthcare" in January 2015, which reported that the number of IDP who had no access to medicines or could not afford them was $27.3 \%$. This research also revealed that the urgent need in humanitarian aid (food and clothes only) was $65.7 \%$, in social assistance $-86.5 \%$, in psychological $-89 \%$, in cultural $-92.7 \%$ [60]. It should be noted that the data obtained as to the needs in humanitarian aid differ considerably due to the fact that in the authors' [of this article] research the humanitarian aid services related not only to satisfying the basic needs in food and clothes, but encompassed a somewhat broader range - stationery, hygiene goods, preparing for winter season, etc.

At the main stage of the experiment (November 2018 - October 2019), the response strategy in social work with IDP and the receiving community was applied by the mentioned kinds of social work. By the psychology-andpedagogic assistance direction, the Center jointly with the "SOS the Children's Villages" cooperated actively with education institutions in order to form a modern, most comfortable for children education environment to assist teachers to cope with the tasks of adaptation of children from vulnerable families to school, to give them an opportunity of overcoming difficulties and develop their abilities to the fullest extent. The following methods and 
measures were suggested: individual consultations by a psychologist; consultations by a social work specialist; sessions with a logopedist; group classes in art-therapy; group classes in parental potential development; mutual assistance groups; individual psycho-therapeutic sessions for children who experienced a trauma; charity initiatives (for instance "A backpack of kindness" - assistance to children in getting ready for school), additional classes in school subjects, etc. The socio-medical assistance was connected with such aspects as recovery (health improvement) that supposes organizing resting holidays for children from the region that suffered from the conflict, covering a certain sum of expenditures on buying medicines for children if prescribed by a doctor, giving out medicines and vitamins, training children and families in a healthy way of life. The information-and-cultural support supposed organization of joint leisure for parents and children, information support as to a family's renewal of their social status, family and social ties (information support in paperwork (restoring documents), various kinds of social payments, etc.), development and propagation of information materials for parents and children. Jointly with the "SOS Children's Villages" the Center provided humanitarian aid in the form of food parcels, hygiene sets, baby-boxes, medicines and vitamins, seasonal clothes and footwear according to the detected needs. It should be noted, that the main programs fulfilled by the Center jointly with the "SOS Children's Villages" are family forms of upbringing, strengthening families, programs within the projects of responses to extraordinary situations. For covering expenditures on responses to extraordinary situations, the grant financing mechanisms are involved.

The final stage of the experiment (December 2019 January 2020) included analyzing the efficiency of applying the response strategy in social work with internally displaced families and the receiving community. In Table 3, the work outcomes are presented. The interpretation of the obtained data was made with the use of $\varphi^{*}$ indicator of Fisher's angular criterion. The statistical significance levels of different values of Fisher's $\varphi^{*}$ criterion were determined from Hubbler's table [61].

The obtained results attest to a positive dynamics in solving the problems of IDP families and communities in the East of Ukraine because, owing to the use of the response strategy in the course of their social support, the percentage of families who need further satisfying needs in the mentioned kind of services by all kinds of assistance (psychology-and-pedagogic, socio-medical, informationand-cultural, and humanitarian) decreased, which attests to activation of their own resources in overcoming the consequences of the conflict to their lives, restoring their potential and social relations, raising the level of their integration into the receiving community. These data match the authors' data on IDP's rehabilitation, integration, and activation within the EU project in the town of Berdyansk [6], when owing to social work with IDP in the places of their compact residence and the community and activation of IDP and local residents' subjectivity, tension in the local community decreased. Nevertheless, the program was not oriented at resilience development, which told on further IDP's migration (at present $10 \%$ of residents there are IDP instead of $20 \%$ at the beginning).

Table 3. Unified actions in the response strategy for emergency situations.

\begin{tabular}{|c|c|c|c|c|}
\hline $\begin{array}{l}\text { The necessity in } \\
\text { satisfying a need } \\
\text { in }\end{array}$ & $\begin{array}{c}\text { \% of the } \\
\text { total } \\
\text { number of } \\
\text { families to } \\
\text { those who } \\
\text { needed } \\
\text { support }\end{array}$ & $\begin{array}{c}\% \text { of the } \\
\text { total } \\
\text { number of } \\
\text { families to } \\
\text { those after } \\
\text { social } \\
\text { support }\end{array}$ & $\varphi *$ emp & $\mathbf{p}$ \\
\hline \multicolumn{5}{|c|}{$\begin{array}{c}\text { Psychology-and-pedagogic assistance } \\
\end{array}$} \\
\hline logopedist services & 12,0 & 2,4 & 4,43 & $<0,001$ \\
\hline $\begin{array}{l}\text { psychologist } \\
\text { services }\end{array}$ & 84,4 & 26,8 & 13,89 & $<0,001$ \\
\hline $\begin{array}{l}\text { a social worker's } \\
\text { services }\end{array}$ & 81,6 & 23,6 & 13,86 & $<0,001$ \\
\hline $\begin{array}{l}\text { improving their } \\
\text { English }\end{array}$ & 25,6 & 17,2 & 2,3 & 0,01 \\
\hline $\begin{array}{l}\text { catching up with } \\
\text { school program }\end{array}$ & 15,2 & 5,2 & 3,81 & $<0,001$ \\
\hline \multicolumn{5}{|c|}{ Socio-medical assistance } \\
\hline $\begin{array}{l}\text { covering } \\
\text { expenditures on } \\
\text { medical treatment } \\
\text { of a child }\end{array}$ & 31,6 & 21,2 & 2,65 & $<0,003$ \\
\hline $\begin{array}{l}\text { recovering (health } \\
\text { improvement) }\end{array}$ & 69,2 & 27,2 & 9,71 & $<0,001$ \\
\hline
\end{tabular}

\begin{tabular}{|l|c|c|c|c|}
\hline \multicolumn{4}{|c|}{ Information-and-cultural assistance } \\
\hline $\begin{array}{l}\text { information } \\
\text { services }\end{array}$ & 64,4 & 15,6 & 11,75 & $<0,001$ \\
\hline $\begin{array}{l}\text { organizing of daily } \\
\text { activities and } \\
\text { leisure }\end{array}$ & 89,6 & 50,4 & 10,13 & $<0,001$ \\
\hline \multicolumn{5}{|c|}{ Humanitarian aid } \\
\hline $\begin{array}{l}\text { non-financial } \\
\text { assistance (school } \\
\text { stationery, food, } \\
\text { hygienic, winter } \\
\text { sets, etc.) }\end{array}$ & 88,4 & 18,0 & 17,56 & $<0,001$ \\
\hline
\end{tabular}

Therefore, the use of the response strategy in social work with internally displaced families and the receiving community is efficient and forms favorable conditions for achieving the goals of sustainable development on the road to their stable future.

\section{Conclusion}

The peculiarities of social work with IDP and the community in Luhansk oblast are that this region is characterized by the dependency of social work on military-and-civil administrations and the territory regime; a large number of IDP; the presence of specific problems and the needs of IDP and the receiving community; IDP's participation in social work as specialists; orientation of local authorities at state assistance programs for IDP acting in Ukraine and not taking into account the peculiarities in the conflict zone; the need in social management under conditions of limited resources; involvement of public organizations to 
providing social services for IDP; the need in orienting at resilience.

The response strategy in social work with internally displaced families and community is directed at renewal of their viability, access to resources, and integration of internally displaced families in the receiving communities. Its content is connected with such unified actions as the necessity in estimating the problem and needs, resources mobilizing, actions coordination, and permanent monitoring of the situation. Social response of this type is based on scientific approaches of various levels and principles of human rights protection, sustainable development perspectives, ensuring multidisciplinary approach, integration, resource mobilizing, eco-sociality, advantages theory, assistance for self-assistance, innovativeness, partnership, vitality, synergy, etc. It supposes implementation of the technology of social support of vulnerable children and families, holding events, application of forms and methods by the directions of psychology-and-pedagogic, socio-medical, information-and-cultural, humanitarian aid, that are determined by actual problems and needs of IDP and community.

Application of the response strategy in social work with internally displaced families and community under conditions of difficult socio-political situation that has formed in Luhansk oblast is efficient because it activates their resources in overcoming the consequences of the conflict, restores their potential and social ties, raises stability of both the family and the community in the context of vision of the perspective of achieving the goal of sustainable development.

The authors see the perspective of further scientific research in theoretic substantiation of possible tactics of influence in social work with internally displaced families and the community within the application of the response strategy in the context of the perspective of their sustainable development, the role of communities in forming the market of various social services and their accessibility in the eastern Ukraine regions that are characterized as having a difficult socio-political situation.

\section{References}

1. Document A/RES/70/1 (United Nations, 2015), https://www.un.org/ga/search/viewm_doc.as p?symbol=A/RES/70/1. Accessed 11 Aug 2020

2. Pro Tsili staloho rozvytku Ukrainy na period do 2030 roku (On the Goals of Sustainable Development of Ukraine till 2030). (Decree of the President of Ukraine, 722 / 2019), https://zakon.rada.gov.ua/laws/show/722/2019\#Text Accessed 21 Aug 2020

3. A. O. Yaroshenko (ed.), Osoblyvosti nadannia medychnykh ta sotsialnykh posluh dlia vrazlyvykh katehorii naselennia $z$ vykorystanniam gendernochutlyvoho pidkhodu (Peculiarities in rendering medical and social services to vulnerable categories of population with the use of gender-sensitive approach). (Alians hromadskoho zdorovia, Kyiv, 2017)

4. I. Trubavina, A. Martyniuk, The content of the training program for the teaching staff working with children of the labour migrants (in the context of sustainable futures). E3S Web Conf. 166, 10001. (2020). doi:10.1051/e3sconf/202016610001

5. Kilkist zareiestrovanykh VPO stanom na 13 kvitnia $2020 \mathrm{r}$. (The number of the registered IDP as of April 13, 2020). https://mtot.gov.ua/ua/kilkistzareestrovanih-vpo-stanom-na-13-kvitnja-2020-r (2020). Accessed 20 Aug 2020

6. I. M. Trubavina (ed.), O. L. Mykhailychenko, K. A. Yurieva, Metodychni rekomendatsii do orhanizatsii fakultatyvnykh zakhodiv $v$ shkolakh $z$ metoiu pryshcheplennia hidnosti, myru ta sotsialnoho konsensusu (Methodology recommendations to organizing extracurricular events at schools to instill dignity, peace, and social consensus). (Planet Print, Kharkiv, 2017).

7. I. M. Trubavina, Dissertation, Luhansk Taras Shevchenko National University, 2009

8. I. M. Trubavina, in Hibrydna viina na Skhodi Ukrainy $v$ mizhdystsyplinarnomu vymiri: vytoky, realii, perspektyvy reintehratsii (Hybrid war in eastern Ukraine in an interdisciplinary dimension: origins, realities, prospects for reintegration), ed. by V.S. Kurylo, S.V. Savchenko, O.L. Karaman (DZ "LNU imeni Tarasa Shevchenka", Starobilsk, 2017), pp. 320-342.

9. O. L. Karaman, Ya. I. Yurkiv, Education and Pedagogical Sciences 1(170), 49-57 (2019)

10. O. L. Glavatska, G. B. Chaikovska, Pedahohichnyi almanakh. 41, 261-266 (2019)

11. S. S. Palchevskyi, Sotsialna pedahohika (Social pedagogy). (Condor, Kyiv, 2005)

12. Yu. L. Trofimov (ed.), Psykholohiia (Psychology). (Lybid, Kyiv, 2001)

13. I. O. Grygorenko, N. M. Savelieva, Sotsialna robota $z$ vnutrishno peremishchenymy osobamy $v$ suchasnykh umovakh (Social work with internally displaced persons in current conditions). (PNPU, Poltava, 2017)

14. N. Gusak, T. Semygina, S. Truhan, Ukrainskyi sotsium 2(53), 65-72 (2015)

15. I. V. Lityaga, Teoretychni osnovy sotsialnoi roboty $z$ vnutrishno peremishchenymy osobamy (Theoretical foundations of social work with internally displaced persons), in International Science-practical conference Current tendencies and factors in development of pedagogic and social sciences, Kyiv, 1-2 February, 2019, vol. 2 (HO "Kyivska naukova orhanizatsiia pedahohiky ta psykholohii”, Kyiv, 2019), p. 112

16. Yu. Pelisiye, Naukovyi visnyk MNU imeni V. O. Sukhomlynskoho: pedahohichni nauky 1(42), 202-205 (2016) 
17. A. V. Anosova, O. V. Bezpalko, T. P. Tsyuman, et al., Sotsialna robota $\mathrm{z}$ vrazlyvymy simiamy ta ditmy (Social work with vulnerable families and children), vol. 2 (Obnova kompani, Kyiv, 2017)

18. Ministerstvo sotsialnoi polityky Ukrainy. Sotsialnyi zakhyst vnutrishno peremishchenykh osib. https://www.msp.gov.ua/news/15904.html (2018). Accessed 20 Aug 2020

19. O. V. Bezpalko, Sotsialna robota v hromadi (Social work in community) (Tsentr navch. lit., Kyiv, 2005)

20. O. V. Berdanova, V. M. Vakulenko, I. V. Valentiuk, A. F. Tkachuk, Stratehichne planuvannia rozvytku obiednanoi terytorialnoi hromady (Strategic planning of a united territorial community development) (Kyiv, 2016)

21. Praktychnyi posibnyk $\mathrm{z}$ pytan orhanizatsii roboty orhaniv mistsevoho samovriaduvannia obiednanykh terytorialnykh hromad. (Practical aid in the issues of work organizing at local self-governing bodies of united territorial communities). Module 5. Stratehichnyi plan rozvytku hromady. (Kyiv, 2016)

22. T. Semyhina, Naukovi zapysky NaUKMA 59, 61-67 (2006)

23. G. Slozanska, V. Polishchuk, Social Work and Education 6(4), 390-407 (2019). doi:10.25128/25206230.19.4.5

24. G. I. Slozanska, Sotsialna robota $v$ terytorialnii hromadi: teorii, modeli ta metody (Social work in a territorial community: theories, models, and methods), ed. by V. A. Polishchuk (Osadtsa Yu. V., Ternopil, 2018).

25. A. Alexander Social work and internally displaced persons (IDPs) in Nigeria: the need for increase social work intervention, in International Conference on Emerging and Contemporary Social Issues, September 12-13, 2018. http://eprints.gouni.edu.ng/id/eprint/2117. Accessed 21 Aug. 2020

26. J. Lambert, Refugees and the environment: The forgotten element of sustainability (European Parliament, Brussels, UK, 2002)

27. J. T. Pardeck, JSSW 15 (2) (1988), https://scholarworks.wmich.edu/jssw/vol15/iss2/11. Accessed 17 Aug 2020

28. K. van Wormer, F.H. Besthorn, T. Keefe, Human behavior and the social environment macro level: Groups, communities, and organizations (Oxford University Press, New York, NY, 2007)

29. K. B. Lai, B. Toliashvili, Social Work and Social Policy in Transition 1 (2), 92-118 (2010)

30. K. E. Miller, Peace and Conflict: Journal of Peace Psychology 4 (4), 365-379 (1998). doi:10.1207/s15327949pac0404_5

31. L. Dominelli, Anti-oppressive social work theory and practice (Palgrave Macmillan, New York, 2002).

32. P. Boccagni, E. Righard, European Journal of Social Work $23 \quad$ (3), 375-383 (2020). doi:10.1080/13691457.2020.1767941
33. A. Carrillo, International Review of the Red Cross. 91 (875), 527-546 (2009). doi:10.1017/S1816383109990427

34. U. U. Bay, in Enclyclopedia of Social Work (Oxford University Press, New York, 2015), pp. 1-20 doi:10.1093/acrefore/9780199975839.013.1166

35. A. Gitterman, in The social workers' desk reference, ed. by A. Roberts, 2nd edn. (Oxford University Press, New York, 2009), pp. 231-234

36. N. Ye. Husak, T. V. Semyhina, S. O. Trukhan, Visnyk NTUU "KPI": Politolohiia. Sotsiolohiia. Pravo 2(22), 161-167 (2014)

37. SOS Children's Villages International. Strategy 2030, https://www.sos-childrensvillages.org/whowe-are/strategy-2030. Accessed 11 Aug 2020

38. Obyazatel'stva SOS v obespechenii vospitaniya kak organizaciya "SOS Detskie Derevni" obespechivaet nailuchshie usloviya vospitaniya dlya detej i molodezhi ("SOS" Obligations in upbringing support. How the "SOS Children's Villages" organization provides the best conditions for children and youth upbringing), https://www.soschildrensvillages.org/getmedia/b8034cb6-caf147c7-8098-

47fb0f890688/SOS_CARE_PROMISE_RU_Web.p df. Accessed 11 Aug 2020

39. SOS Dytiachi Mistechka u sviti (“SOS Children's Villages" in the world), https://sos-ukraine.org/sosdityachi-mistechka/. Accessed 18 Aug 2020

40. T. Semyhina, Visnyk Akademii pratsi, sotsialnykh vidnosyn i turyzmu 2, 11-27 (2018)

41. Kafedra sotsialnoi pedahohiky. Luhanskyi natsionalnyi universytet imeni Tarasa Shevchenka (The Department of Social Pedagogy at Luhansk Taras Shevchenko National University). http://luguniv.edu.ua/?page_id=16387. Accessed 21 Aug 2020

42. O. L. Karaman, V. S. Kurylo, S. V. Savchenko, Visnyk Luhanskoho natsionalnoho universytetu imeni Tarasa Shevchenka: pedahohichni nauky 8(322), II, 201-219 (2018)

43. Pro viiskovo-tsyvilni administratsii (On militaryand-civil administrations). Zakon Ukrainy, 03.02.2015, 141-VIII. https://zakon.rada.gov.ua/laws/show/14119 ?find $=1 \&$ text $=\% \mathrm{D} 1 \% 80 \% \mathrm{D} 0 \% \mathrm{~B} 5 \% \mathrm{D} 0 \% \mathrm{~B} 6 \% \mathrm{D} 0$ \%B8\%D0\%BC\#Text Accessed 21 Aug 2020

44. Kilkist zareiestrovanykh VPO stanom na 13 kvitnia 2020 r. (The number of registered IDP as of April 13, 2020), https://mtot.gov.ua/ua/kilkist-zareestrovanihvpo-stanom-na-13-kvitnja-2020-r. Accessed 20 Aug 2020

45. M. Demiyanenko, Ukraina: podii, fakty, komentari. 3, 34-43 http://nbuviap.gov.ua/images/ukraine/2018/3.pdf. Accessed 12 Aug 2020

46. N. Gusak (ed.), Psykhosotsialna pidtrymka v umovakh nadzvychainykh sytuatsii: pidkhid 
rezyliiens: posibnyk $z$ provedennia treninhu (Psychosocial support in conditions of extraordinary situations: resilience approach: teaching aid in conducting a training) (NaUKMA, Kyiv, 2017)

47. M. B. Svystovych, Derzhavne upravlinnia: teoriia ta praktyka 2, 37-43 (2013)

48. Zahalna deklaratsiia prav liudyny (The General Declaration of Human Rights). (United Nations, 1948), https://zakon.rada.gov.ua/laws/show/995_01 5\#Text. Accessed 16 Aug 2020

49. Konventsiia pro prava dytyny (Convention on Human Rights). (United Nations, 1948), https://zakon.rada.gov.ua/laws/show/995_021\#Text. Accessed 20 Aug 2020

50. Kerivni pryntsypy OON shchodo alternatyvnoho dohliadu za ditmy (The UN Guidelines as to Alternative Childcare). (United Nations, A/RES/64/142, 2010), https://sos-ukraine.org/wpcontent/uploads/2020/04/kerivni-princzipi-shhodoalternativnogo-doglyadu-za-ditmi.pdf. Accessed 16 Aug 2020

51. Spravochnik po chrezvychajnym situaciyam Upravlenie Verhovnogo komissara OON po delam bezhencev. (The Manual on Extraordinary Situations. The Office of the UN High Commissioner for Refugees) (1999), https://www.refworld.org/cgibin/texis/vtx/rwmain/opendocpdf.pdf?reldoc $=y \& d o c$ $\mathrm{id}=4 \mathrm{c} 0634752$. Accessed 11 Aug 2020

52. Mobilizatsiia hromad: dosvid PROON u realizatsii pidkhodu hromadskoi bezpeky i sotsialnoi zghurtovanosti: posibnyk dlia mobilizatoriv hromad (Communities mobilization: The UN experience in implementing the civil safety and social unity approach: training aid for communities mobilizers), https://www.undp.org/content/dam/ukraine/docs/DG /1/posibnik_mob_gromad_ua_vnutr_blok_text_30_1 0_2018_sm\%20(1).pdf. Accessed $2 \overline{1}$ Aug 2020

53. SOS Dytiachi Mistechka Ukrainy. Nashi prohramy ("SOS Children's Villages. Ukraine" Our programs), https://sos-ukraine.org/nashi-programi/. Accessed 18 Aug 2020

54. O. A. Andrukhovych,

L. S. Volynets, D. S. Kasianova, I. V. Shcherbak, Povernennia dodomu: reintehratsiia ditei z alternatyvnykh form dohliadu: metod. rekomendatsii (Coming home; reintegration of children through alternative forms of childcare: methodology recommendations) (Kyiv, 2020)

55. O. F. Novikova, O. V. Pankova, Problemy ekonomiky. 3(37), 217-225 (2018)

56. L. S. Volynets (ed.). Psykhosotsialna dopomoha vnutrishno peremishchenym ditiam, yikhnim batkam ta simiam z ditmy zi Skhodu Ukrainy (Psycho-social assistance to internally displaced children, their parents, and families from the East of Ukraine). (Kalyta, Kyiv, 2015)

57. U. Ya. Sadova, O. T. Ryndzak, N. I. Andrusyshyn, Demohrafiia ta sotsialna ekonomika 3 (28), 171-185 (2016)
58. A. Solodko, T. Doroniuk, Vyroblennia polityky shchodo vnutrishno peremishchenykh osib v Ukraini (Development of policies concerning the internally displaced persons in Ukraine) (2015), https://www.irf.ua/content/files/dp-2015-7.pdf. Accessed 16 Aug 2020

59. Employment needs assessment and employability of internally displaced persons in Ukraine: summary of survey findings and recommendations. ILO Decent Work Technical Support Team and Country Office for Central and Eastern Europe (ILO, Budapest, 2016)

60. Otsinka potreb vnutrishno peremishchenykh osib v Ukraini ta posluh dlia nykh (Estimation of internally displaced persons' needs in Ukraine and services for them), http://www.lhsi.org.ua/images/2015/Doslidzh ennya_VPO_LHSI2015.pdf. Accessed 16 Aug 2020

61. Ye. V. Sidorenko, Metody matematicheskoj obrabotki $v$ psihologii (Methods of mathematical interpretation in psychology) (Rech, SanktPeterburg, 2000) 